\title{
JEJAK SEJARAH DALAM SASTRA LISAN DI NUSANTARA
}

\author{
Muhammad Fadli Muslimin ${ }^{a}$, Mira Utami ${ }^{\text {b }}$ \\ ${ }^{a}$ Fakultas Sastra, Universitas Muslim Indonesia \\ Jl. Urip Sumoharjo KM. 5, MakassarSulawesi Selatan, Indonesia \\ Pos-el : fadlimuslimin@gmail.com \\ ${ }^{\mathrm{b}}$ Alumuni, Ilmu Sastra UGM \\ Jalan Sosio Humaniora, Bulaksumur Caturtunggal, Kec. Depok, Kabupaten \\ Sleman, Daerah Istimewa Yogyakarta, Indonesia \\ Pos-el:koharami87@gmail.com
}

\begin{abstract}
Abstrak
Sastra lisan sangat berkaitan erat dengan sejarah ketika sastra lisan yang merupakan bagian tradisi lisan adalah wadah utama dalam penyampaianfakta-faktasejarah.Oleh sebab itu, pelacakan fakta-fakta sejarah yang ada di dalam sastra lisan yang ada di nusantara. Tujuan daripenelitian ini adalah mengungkapkan jejak-jejak sejarah yang ada pada tradisi lisan yang ada di nusantara khususnya yang terdapat pada sastra lisan Bugis, Minangkabau, Sunda, Banjar, Kerinci, dan Sentani. Metode yang digunakan adalah deskriptif analisis memanfaatkan teori dari Jan M. Vansina tentang oral tradition as history. Hasil penelitian menunjukkan bahwa muatan sejarah yang terkandung dalam sastra lisan yang menceritakan asal-muasal, kehidupan raja-raja masa lalu dan pada penceritaannya cenderung bersifat personifikasi.
\end{abstract}

KataKunci: sastra lisan, fakta sejarah, asal-muasal

\section{The Trace of History in Oral Literature in Indonesia}

\begin{abstract}
The oral literature had a close relation to history, where oral literature which is part of oral tradition become the main container in the delivery of historical facts. Therefore, tracking historical facts in oral literature in the archipelago. The purpose of this study is to reveal the historical traces that exist in oral traditions in Indonesia, especially those found in Bugis, Minangkabau, Sundanese, Banjar, Kerinci, and Sentani oral literature. The method used is the descriptive analysis utilizing the theory of Jan M. Vansina about oral tradition as history. The results of the research show that the historical content in oral literature tells about the origins of humans, the lives of the past kings, and their narrative tends to be personified.
\end{abstract}

Keywords: oral literature, historical facts, origins

\section{PENDAHULUAN}

Indonesia mempunyai lebih dari tiga belas ribu pulau yang didiami oleh sekitar 1.340 suku dengan ragam bahasanya masingmasing. Tercatat ada 742 bahasa menurut data yang dikeluarkan Summer Institute of Linguistics (SIL, 2006) (Aritonang et al., 2017) bahasa dituturkan masyarakat dengan kekhasan langue dan parole-nya, walaupun saat ini sudah banyak bahasa asli suku-suku di Indonesia yang sudah mati. Demikian pun adat istiadat dan budaya masyarakat yang membentuk folklor, yang setiap daerah mempunyai tradisi sendiri yang berbeda-beda walaupun pada akhirnya akan muncul kesamaan dalam segi makna dan pesan yang termuat di dalam tradisi-tradisi tersebut.

Sastra lisan yang menjadi bagian dari tradisi lisan dan folklor memiliki ciri khas yang mencerminkan kehidupan dan pola masyarakat tempatia muncul, berkembang dan dipertahankan oleh masyarakat penuturnya. Begitu pun sejarah pada masyarakat tersebut juga menjadi salah satu aspek yang menjadi material dasar sastra lisan. Setiap daerah 
dan kelompok masyarakat memiliki latar belakang sejarahnya sendiri.

Sastra lisan adalah bagian dari tradisi lisan yang menjadi salah satu ciri budaya Nusantara. Tradisi lisan telah membumi di Nusantara dan menjadi bagian dari perkembangan masyarakat di Indonesia. Tradisi lisan Nusantara sangat banyak jenisnya. Tradisi yang mengakar ini menjadi wadah untuk penyampaian pesan, pendidikan, berita, hiburan dan tujuantujuan lainnya sebelum ditemukannya aksara. (Amir (2013), tradisi lisan tidak hanya dalam bentuk tuturan semata, tetapi juga dalam bentuk sastra dan seni, serta aspek kelisanan lainnya. Bentuk-bentuk wadah penyebaran tradisi lisan ini di antaranya pertuturan adat yang dilakukan dalam upacara-upacara adat, mantra yang digunakan dalam ritual-ritual adat, lagu permainan anak-anak, bahkan lagu-lagu pujian bagi orang yang meninggal, dan dendang untuk memikat hewan buruan atau menangkap hewan buas (hlm.4)

Tradisi lisan dan sastra lisan pernah menjadi kontradiksi dalam pengistilahan konsep yang memadai pada masa sebelum dikenalnya aksara. Sastra lisan sebagai bagian dari tradisi lisan yang tidak dapat dipisahkan satu sama lain karena adanya keterikatan sejarah dengan tradisi itu sendiri. Tradisi lisan pun digunakan sebagai media untuk menyampaikan peristiwa-peristiwa sejarah kepada masyarakat dan generasi penerus melalui aspek-aspek kelisanan. Sebagai contoh pada Dalam tradisi lisan dunia, cerita dan sejarah menjadi bagian yang sangat penting dalam peradaban ketika ditemukan bahwa ajaran Injil, naskah Perjanjian Lama, cerita kuno Yunani Iliad dan Odyssey dan banyak lagi sastra kuno lainnya telah menjadi akar dari tradisi lisan masyarakat Eropa.

Menurut Lord, (Lord, 1971) "the world of "orality" is a world of talk. One literally hears of what has happened in the past, as well as of what is happening in one's own day". Dari pernyataan tersebut dapat diartikan bahwa dunia kelisanan adalah dunia tutur. Seseorang secara harfiah mendengar apa yang telah terjadi di masa lalu, seperti halnya apa yang terjadi di zamannya sendiri (hlm.19).

Lebih lanjut, Lord dalam The Singer of Tales menuliskan hasil penelitiannya bersama Parry, bahwa sastra lisan adalah sastra yang dipelajari, digubah, dan disebarkan secara lisan. Eksistensi sastra lisan menjadi penting karena tidak membutuhkan media tulisan. Tetapi kemudian definisi tersebut belum memberikan gambaran jelas berkaitan dengan definisi sastra lisan, hanya sebatas penjelasan secara teknis. Jelasnya, pendefinisian sastra lisan menurut Amir (2013), sastra lisan adalah seni bahasa yang diwujudkan dalam pertunjukan oleh seniman dan dinikmati secara lisan oleh khalayak, menggunakan bahasa dengan ragam puitika dan estetika masyarakat bahasanya (hlm. 78). Berikutnya, dalam ruang lingkup yang lebih luas, sastra lisan dapat dikatakan sebagai sesuatu yang harus dituturkan atau ditampilkan oleh orang yang memahami dan mengetahui sebenarbenarnya isi dari sastra tersebut, atau yang disebut sebagai seniman sastra lisan, yang kemudian dipertontonkan kepada khalayak (Amir, 2013)

Peradaban Nusantara sendiri dibangun dari sejarah, sejarah yang baik adalah sejarah yang disampaikan sesuai dengan fakta-fakta sesungguhnya. Sejarah dan sastra adalah dua dimensi yang berbeda, menurut White (1990), halyang membedakan sejarah dan sastra adalah isinya, sejarah lebih mementingkan isi daripada bentuk (hlm. 26--27). Isi cerita sejarah adalah peristiwa dan tokoh-tokoh yang nyata, sedangkan isi cerita sastra adalah peristiwa dan tokoh-tokoh yang diciptakan viaimajinasi (Ratna, 2010) Penting dipahami bahwa dalam sastra khususnya sastra lisan, sejarah seringkali muncul pada setiap waktu tertentu (hlm. 334--335). Hal tersebut berkaitan dengan posisi sastra dan sejarah hidup di dunia yang berdampingan yang masyarakat sebagai objeknya. Secara lisan oleh 
penutur-penuturnya melalui bahasa kelompok mereka masing-masing sesuai dengan kondisi geografis dan keadaan sosial kemasyarakatannya. Fakta-fakta sejarah disampaikan melalui cerita dengan tujuan menjaga kelestarian pengetahuan terhadap sejarah nenek moyang agar masyarakat kelompok tertentu dapat memahami dan menyadari identitas dan asal-usul mereka, juga bagaimana kehidupan pendahulu mereka membentuk karakter dan kehidupan generasi penerusnya. Oleh karena itu, dapat dikatakan bahwa sastra lisan adalah salah satu wadah dalam penyampaian fakta-fakta sejarah.

Penelitian ini berfokus pada pengungkapan fakta-fakta sejarah yang ada dalam sastra lisan. Adanya fakta sejarah di dalam sastra lisan sering kali dianggap sebagai fakta yang bersifat imajinatif dan tidak merepresentasikan fakta sesungguhnya dari dalam sejarah itu sendiri, sehingga sastra lisan kerap tidak dipandang sebagai wadah yang tepat untuk penyampai sejarah. Hal ini juga ditegaskan di dalam diskusi pada rangkaian Konferensi Nasional Sejarah (KNSS) X di Jakarta, bahwa karya sastra memainkan perannya dalam perjalanan sejarah bangsa Indonesia ("Fakta Sejarah dalam Karya Sastra Indonesia Direktorat Jendral Kebudayaan," 2016)

Menulis karya sastra berdasarkan fakta sejarah atau berlatar sejarah berbeda dengan menarasikan fakta sejarah melalui karya sastra. Karya berlatar sejarah, misalnya yang ditulis oleh Leila S.Chudori, dalam Pulang, yang berkisah peristiwa sejarah besar di Indonesia dan dunia, yaitu peristiwa 30 September 1965, Perancis Mei 1968, dan Indonesia Mei 1998 (Khakim, 2016). Tulisan yang menarasikan fakta sejarah dapat dilihat pada penelitian yang ditulis oleh Faradika Darman, yaitu Realitas Sejarah dalam Sastra Lisan Kapata Perang Kapahaha Desa Morella, Pulau Ambon. Ia menyatakan bahwa kapata perang Kapahaha menyimpan nilai sejarah yang dapat dijadikan sumber penulisan sejarah khususnya di Morella yang menceritakan tentang perang karyat Kapahaha dengan Belanda (Darman, 2017).

Selain itu, penelitian lain yang membahas tentang kandungan sejarah dalam karya sastra, memberikan kita informasi terkait bagaimana sejarah dikemas dalam konteks saat ini. Misalnya pada penelitian yang dilakukan oleh Nurul Laili yang berjudul Kajian Historisisme dalam Novel Keindahan dan Kesedihan Karya Yasunari Kawabata. Ia mengidentifikasi bahwa bagaimana sejarah direkonstruksi melalui pendekatan sastra dengan meletakkan imajinasi Yasunari Kawabata yang segaris dengan kondisi kehidupan dia di Jepang sehingga membuka sumber sejarah pada situasi politik dan sosial pada masa Jepang periode 1960-an (Laili, 2013).

Berbeda dengan sastra lisan yang penuturannya dilakukan secara lisan secara turun temurun, sastra lisan yang merupakan bagian dari tradisi lisan, mengusung hakikat yang mencakup segala hal yang berhubungan dengan sastra, bahasa, sejarah, biografi, dan berbagai pengetahuan serta jenis kesenian lain. Hakikat inilah yang menjadi dasar bahwa segala bentuk pengetahuan lisan dapat dijadikan acuan dalam melihat kerangka sejarah suatu peristiwa. Meskipun dibingkai dalam kaidah sastra, tidak dapat dipungkiri bahwa muatan-muatan sejarah sebagai wujud interaksi penutur dengan lingkungannya menghasilkan dasar pengetahuan sejarah lokal dan merupakan catatan tentang politik kebudayaan (Dirija, 2005).

Dalam historiografi Indonesia, untuk menentukan informasi dan sejauh mana kelisanan dapat dimanfaatkan untuk dijadikan sumber sejarah, diperlukan serangkaian langkah metodologis dan teknis mengenai penggunaan sumbersumber lisan dan masalah-masalah yang muncul darinya (Erman, 2011). Pada penelitian ini, persoalan metodologis terkait penentuan sumber sejarah tersebut 
bukan menjadi fokus kami, melainkan bagaimana sejarah disajikan di dalam sastra lisan. Sebagai salah satu sumber lisan, sastra lisan sebagai produk kesenian memuat pengetahuan sejarah yang dapat menambah khazanah sumber lisan lainnya bagi historiografi Indonesia.

Masih minimnya kajian yang memfokuskan pada fakta sejarah yang termuat di dalam sastra lisan mengakibatkan perlunya kajian yang lebih mendalam pada setiap sastra lisan Indonesia. Penelitian yang dilakukan Faradika Darman yang telah disinggung sebelumnya pun merupakan upaya untuk menggali fakta sejarah tersebut. Realitas Sejarah dalam Sastra Lisan Kapata Perang Kapahaha Desa Morella, Pulau Ambon (Darman, 2017) memberikan gambaran bahwa makna historis sastra lisan adalah refleksi cerita sejarah masa lalu.

Penelitian ini, selain mendiskusikan fakta sejarah yang terdapat pada sastra lisan, juga memperluas objek penelitian yang tidak hanya pada satu sastra lisan, tapi pada enam sastra lisan.

\section{TEORI}

Sastra lisan adalah media sekaligus sumber sejarah, yang artinya adalah dalam penuturan cerita dalam sastra lisan mengandung gagasan-gagasan yang berkaitan dengan sejarah suatu peradaban wilayah tertentu. Sumber-sumber sejarah yang diperoleh oleh penutur selanjutnya ditransformasikan menjadi cerita yang berbentuk lisan, dikarenakan media tutur menjadi media yang efektif untuk menyampaikan informasi tersebut. Dalam sastra lisan, subjek yang direduksi secara minimum atau terbatas merupakan interpretasi pesan/informasi yang diambil dalam kurun waktu tertentu dan hal itu berasal dari kejadian tertentu yang telah diangkat dan berkembang menjadi sejarah.

Tradisi lisan yang terdapat di Indonesia berkembang dan menjadi tradisi pada zamannya, karenapada saat itu aksara belum menyentuh setiap lapisan masyarakat. Oleh karena itu, digunakanlah teknik mengingat (remembering) agar tuturan-tuturan yang muncul dalam berbagai bentuk tersebut dapat dilestarikan. Begitu pun jejak sejarah yang terjadi pada periode waktu tertentu, digubah menjadi berbagai bentuk tuturan, dihafalkan, kemudian disampaikan dengan maksud menjaga keberlangsungan fakta-fakta tersebut. Oleh karena itu, sastra lisan merupakan salah satu media penyampai pesan sejarah. Jan M Vansina menyebutnya The Generation of Messages, artinya setiap situasi tempat orang-orang berbicara menghasilkan pesan, beberapa dari pesan tersebut diulang dan selanjutnya menjadi awal proses transmisi (Vansina, 1985). Pertanyaannya adalah jejak dan pesan sejarah apa yang hendak disampaikan di dalam sastra lisan tersebut. Dengan begitu, generasi muda dan dapat mendapatkan gambaran sejarah tertentu yang mengandung nilai-nilai, karakter, ataupun identitas daerah, maupun bangsa agar dapat menyadari dan memahami pentingnya mempelajari kaitan antara sejarah dan sastra lisan, agar tidak kehilangan identitasnya sebagai bagian dari Nusantara

Seperti yang dijelaskan oleh Taum (Taum, 2011)dalam bukunya "Studi Sastra Lisan", sastra lisan adalah sekelompok teks yang disebarkan dan diturun-temurunkan secara lisan, yang secara intrinsik mengandung saranan-sarana kesusastraan dan memiliki efek estetik dalam kaitannya dengan konteks moral maupun kultur dari sekelompok masyarakat tertentu.

Sementara itu, menurut rumusan UNESCO, sastra lisan adalah bagian dari tradisi lisan yang diwariskan dalam ruang dan waktu dengan ujaran dan tindakan (Hutomo, 1991). Bentuk tradisi lisan yang seperti itu juga mengacu kepada sejarah perkembangan sastra di Barat, bahwa budaya manuskrip selalu memiliki bagianbagian yang dilisankan, walaupun kemudian sudah hadir tradisi cetak sebagai cara pendokumentasian. Sejak zaman kuno hingga memasuki abad kedelapan belas, 
karya sastra sebagian besar dibuat untuk dibacakan dengan keras kepada penontonnya, bahkan walaupun jika dibuat dalam bentuk tulisan. Membaca keraskeras sangat lazim dilakukan di depan keluarga atau kelompok kecil lainnya hingga awal abad kedua puluh. Diduga para sastrawan Eropa di sekitar abad pertengahan melanjutkan praktik klasik, yaitu menulis karya sastra untuk dibacakan keras-keras.

Lebih lanjut menurut Hutomo, sastra lisan adalah bentuk-bentuk kesusastraan atau seni sastra yang diekspresikan secara lisan. Sastra lisan hanya mengacu kepada teks-teks lisan yang bernilai sastra. Sementaraitu, tradisi lisan lebih luas jangkauannya yang mencakup teknologi tradisional, hukum adat, tarian rakyat dan makanan tradisional (Danandjaja, 1991). Sastra lisan dengan berbagai genrenya mengalami perkembangan, kemunduran bahkan kepunahan (Amir, 2013). Pernyataan tersebut dapat memberikan gambaran akan kondisi sastra lisan dari awal hingga sekarang yang ternyata tidak hanya stagnan dengan bentuk awalnya, tetapi mengalami perubahan dan modifikasi-modifikasi yang dibutuhkan agar dapat terus disampaikan kepada generasi muda dan dapat diterima dengan lebih mudah. Sastra lisan yang menjadi bagian dari tradisi lisan menuntut adanya penutur yang masih mampu menyampaikan isi dari cerita-cerita tersebut. Amir menyampaikan bahwa sastra lisan memiliki penutur atau penampil adalah orang-orang yang sudah berlatih untuk itu, di mana untuk khalayak penikmatnya mempunyai kesadaran estetis, sehingga antara penampil dan khalayaknya sudah mempunyai standar nilai estetis (hlm.70). Seperti yang sudah dijelaskan di bagian sebelumnya, jenis cerita yang terdapat sastra lisan sangat beraneka ragam. Contohnya, asal-usul kejadian, hiburan, nilai moral, dan sebagainya.

Pada jenis sastra lisan yang menceritakan tentang asal-usul kejadian, terdapat unsur-unsur sejarah yang menjadi tema sentral yang merekam fakta-fakta terkait sebagai informasi yang sifatnya harus diteruskan untuk menjaga agar informasi sejarah tersebut tetap hidup. Vansinamenyatakan bahwa isu sejarah hanya dapat diterima dalam lingkup yang kecil selama masih dapat diingat. Isu yang sudah ada sebelumnya berkembang dalam durasi jangka waktu yang cukup lama dan berbeda kemudian diterima menjadi sejarah yang berbeda dari sumber yang berbeda. Data yang ada tetap diaktualisasikan sekalipun dalam cakupan informasi yang kecil. Lebih lanjut, subjek yang direduksi secara minimum merupakan interpretasi informasi yang diambil dalam kurun waktu tertentu. Hal tersebut berasal dari kejadian tertentu dan interpretasi mengenai informasi dan cerita yang didukung dengan data-data pun berkembang menjadi sejarah. Dengan demikian, dapat dikatakan bahwa sastra lisan merupakan hasil reduksi pemaknaan atas satu peristiwa yang dianggap penting, lalu diangkat menjadi peristiwa sejarah. Informasi yang terkandung di dalamnya serta merta dibuat masuk akal dan dipahami sebagai pesan yang berasal dari periode zaman itu.

\section{METODE}

Penelitian inimerupakan penelitian deskriptif. Untuk mengumpulkan jejakjejak sejarah yang ada di masyarakat khususnya fakta-fakta sejarah yang tidak terdokumentasikan, sumber-sumber informasi sejarah yang terdapat dalam sastralisan dikumpulkan dan diformulasikan sehingga didapat rekam jejak sejarahnya. Objek sastra lisan yang telah dibukukan menjadi sumber tunggal yang digunakan, yaitu pada sastra lisan Bugis, Minangkabau, Sunda, Banjar, Kerinci, dan Sentani. Pembacaan secara komprehensif dilakukan untuk mengidentifikasi muatan sejarah yang terdapat pada sastra lisan tersebut. Setelah itu, dikelompokkan berdasarkan daerah masing-masing dan kemudian dianalisis unsur-unsur sejarah yang ada. 


\section{HASIL DAN PEMBAHASAN Perwujudan Sastra Lisan Nusantara}

Sastra lisan yang menjadi bagian dari tradisi lisan dan folklor memiliki ciri khas yang mencerminkan kehidupan dan pola masyarakat tempat ia muncul, berkembang dan dipertahankan oleh masyarakat penuturnya. Seiring berjalannya waktu, upaya untuk tetap melestarikan sastra lisan ditempuh dengan berbagai cara, salah satunya adalah dengan pendokumentasian secara cetak.

Sastra lisan dalam bentuk cetak yang digunakan yakni sastra lisan Bugis, Minangkabau, Sunda, Banjar, Kerinci, dan Sentani.

Muatan sejarah yang melekat pada masyarakat tersebut menjadi salah satu aspek yang menjadi material dasar karya sastra lisan yang turut terdokumentasi. Setiap daerah dan kelompok masyarakat memiliki latar belakang sejarahnya sendiri. Berikut adalah contoh beberapa daerah dengan sastra lisannya masingmasing beserta kandungannya.

\section{Sastra Lisan Bugis}

Bugis adalah salah satu dari empat suku terbesar yang ada di Sulawesi Selatan. Persebaran suku Bugis dapat ditemukan di kabupaten-kabupaten yang ada di Sulawesi Selatan yaitu Bulukumba, Sinjai, Bone, Soppeng, Wajo, SidenrengRappang, Pinrang, Polewali-Mamasa, Enrekang, Luwu, Pare-Pare, Barru, Pangkajene Kepulauan dan Maros.

Sastra lisan dalam bahasa Bugis jumlahnya cukup banyak, tetapi yang telah berhasil direkam, ditulis dan diperbanyak masih sangat sedikit. Beberapa di antaranya dimuat dalam cerita rakyat, terbitan Balai Pustaka (1963). Sastra lisan yang terdapat di kebudayaan yang ada di Bugis bukan tidak mungkin akan tergerus oleh zaman yang sedemikian pesatnya meninggalkan tradisi lisan yang telah lama dipegang masyarakat Bugis.

Sebagaimana definisi sastra lisan yaitu sastra yang disampaikan secara lisan (Amir, 2013) begitu pula yang terjadi di Bugis. Setiap sastra lisan dituturkan secara lisan dengan maksud secara umum yaitu memberi identitas kepada khayalaknya, dapat menjadi pusat komunikasi dan juga merupakan salah satu unsur penting untuk membangun ikatan kelompok atau ikatan kampung (hlm.18).

Jenis sastra lisan yang terdapat pada sastra lisan Bugis dibagi ke dalam tiga kelompok besar yaitu cerita hiburan, cerita pendidikan, dan asal-mula. Setiap cerita mengandung nilai-nilai tersendiri yang ingin diungkapkan oleh penuturnya, dengan menggunakan bahasa Bugis.

Total jumlah sastra lisan yang terdapat dalam kelompok masyarakat Bugis diketahui sejumlah 74 buah melalui sebuah penelitian yang dilakukan oleh Pusat Pembinaan dan Pengembangan Bahasa Departemen Pendidikan dan Kebudayaan Indonesia pada tahun 1981.

Salah satu jenis kelompok sastra lisan yaitu asal-mula yang mengisahkan tentang asal mula pembentukan identitas kerajaan yang ada di Sulawesi Selatan, dituturkan melalui serangkaian sastra lisan yaitu pada cerita "Ammulangenna Nariaseng Kampong Matajang Sibawa Kampong Manurung" yang berarti 'Asalmula Nama Kampung Matajang dan kampung Manurung'e di Bone'. Sastra lisan ini bercerita asal mula lahirnya sebuah kampung yang bernama Matajang Sibawa dan Manurung. Teks dari sastra lisan ini secara utuh dikutip dari buku sastra lisan Bugis yang telah di terjemahkan ke dalam bahasa Indonesia (Fachruddin, 1981). Selainitu, terdapat juga cerita serupa yang mengisahkan proses penamaan sebuah daerah yang berkaitan dengan keberadaan kerajaan juga pada waktu, yaitu "Asal-mula Nama Masewali dan Malaka"(hlm.105).

Jenis sastra lisan yang terdapat di Bugis tidak banyak yang menceritakan tentang sejarah secara eksplisit, pun sastra lisan di atas tidak secara harfiah menjelaskan tentang sejarah yang benarbenar terjadi karena sastra lisan Bugis menggambarkan angan-angan yang mencerminkan sikap pandangan dan jalan 
pikiran masyarakat Bugis (Koentjaraningrat, 2009) Meskipun demikian, cerita yang tergambar dalam sastra lisan tersebut tetap merepresentasikan kejadian sesungguhnya yang ada di Bone pada saat itu.

\section{Sastra Lisan Minangkabau}

Setiap daerah di Indonesia telah mengenal adanya sastra lisan yang hidup berdampingan dengan sastra tulisan, begitupun di Sumatera. Salah satunyaadalahperadaban Minangkabau. Sastra lisan Minangkabau merupakan salah satu warisan budaya nusantara yang memiliki nilai-nilai berharga dengan perannya yang sangat penting dalam kehidupan masyarakat Minangkabau (Bakar, 1979). Lebih lanjut, Bakar menyampaikan jenis-jenis sastra lisan Minangkabau yang sangat beragam, seperti kaba, tambo, pepatah-petitih, sisomba, mantra, perumpamaan, peribahasa, talibun, dan pantun. Jenis sastra lisan yang telah disebutkan selain tambo, biasanya terdapat dalam kaba. Tukang-tukang kaba biasanya fasih sekali menjalinkan jenis-jenis sastra lisan tersebut saat bakaba (aktvitas penyampaian kaba oleh tukang kaba) sehingga kaba bisa dikatakan mempunyai sifat yang lebih kompleks (hlm. 8).Jenis sastra lisan yang akan diambil sebagai contoh dalamtulisaniniadalah tambo.

Dalam kebudayaan Minangkabau, tambo merupakan salah satu jenis sastra lisan yang berisikan informasi mengenai sejarah suku bangsa Minangkabau, asalusul negeri serta adat istiadatnya. Tambo juga dapat disebut sebagai historiografi tradisional, atau penulisan sejarah suatu negeri berdasarkan kepercayaan turun temurun masyarakat setempat (Djamaris, 1991). Lebih lanjut, tambo Minangkabau dalam perkembangannya kemudian dituliskan dalam bahasa Melayu berbentuk prosa, sebagian besarnya dalam huruf Arab-Melayu dan sebagian kecilnya lagi dalam bahasa latin sebagai bentuk preservasi.
Banyak nama negeri yang asalusulnya muncul dalam tambo. Nama Minangkabau muncul dari peristiwa menangnya kerbau orang yang mendiami daerah Minangkabau pertama kalinya saat melawan kerbau orang yang datang dari seberang laut dengan maksud menaklukkan negeri tersebut. Dengan tipu muslihat, kerbau jantan bertubuh besar milik orang seberang laut dapat dikalahkan, karena masyarakat negeri tersebut menggunakan anak kerbau yang masih menyusu. Anak kerbau tersebut dibiarkan kelaparan selama beberapa hari hingga datanglah waktunya untuk berduel dengan kerbau seberang. Kepala anak kerbau dipasangi tanduk dari besi, sehingga ketika si anak kerbau dilepas, dia segera menuju kerbau milik orang seberang untuk menyusu. Dan robeklah perut kerbau jantan tersebut oleh tanduk besi, hingga kemenangan pun jatuh ke tangan masyarakat negeri. Dari peristiwa itu, tersebutlah negeri itu sebagai Minangkabau yang berasal dari kata menang dan kabau (kerbau).

Sementara itu, nama daerah Pagaruyung yang sampai saat ini dikenal sebagai salah satu kerajaan Minangkabau yang termasyhur, berdasarkan pada cerita peristiwa pembuatan pagar tempat mandi Putri Raja yang terbuat dari ruyung. Ceritanya bermula saat Daulat yang Dipertuan pindah ke suatu negeri dengan membawa tujuh orang lelaki dan tujuh orang perempuan, serta tiga orang penghulu. Di negeri itu, Puti Jamilan hamil. Namun, ketika anaknya sudah lahir, Puti Jamilan tidak mau membawa anaknya mandi ke sungai karena banyaknya buaya. Oleh karena itu, Daulat yang Dipertuan memerintahkan rakyat untuk memagari sungai tempat mandi Putri dengan ruyung (sejenis kayu keras dari batang enau atau kelapa), sehingga kemudian negeri tersebut diberi nama Pagaruyung, yang secara etimologi berasal dari kata pagar dan ruyung. 


\section{Sastra Lisan Sunda}

Sastra lisan Sunda memiliki beberapa bentuk yaitu cerita, puisi dan drama, tetapi dalam hal ini yang telah diteliti adalah cerita. Seperti kebanyakan sastra lisan, genre dari sastra lisan yang berasal dari tanah Pasundan cenderung bersifat fiksi, dapat dilihat dari jenis-jenis cerita yang terdapat pada sastra lisan Sunda, misalnya cerita makhluk jadi-jadian, cerita asal-usul suatu keadaan atau nama, dan cerita siluman-siluman (Rusyana, 1978). Meskipun demikian, dalam sastra lisan Sunda terdapat beberapa cerita yang merekam jejak sejarah.

Sastra lisan Sunda lahir dari bentuk interaksi antara masyarakat yang bersuku Sunda. Cerita-cerita yang disampaikan oleh penutur cerita pada waktu berkumpul, misalnya hari-hari keagamaan, rapat, atau kedatangan pembesar. Penceritaan biasanya terjadi saat berkumpulnya beberapa orang yang kemudian bercerita. Umumnya yang melakukan ini adalah orang yang lebih tua.

Tujuan dari bercerita secara umum adalah memberikan sejarah-sejarah yang berkaitan tentang nenek moyang, asal-usul dan benda pusaka, selain itu untuk mengetahuihubungan-hubungan

kekerabatan antar keluarga dan yang terpenting adalah agar semua orang terhibur.

Salah satu cerita, yaitu "Aria Banjaran" menceritakan sejarah masa kolonial Belanda. Dikisahkan seorang wedana atas perintah kompeni membuka sebuah hutan di daerah Banjaran. Di daerah itu mereka membuat lahan pertanian dan perkebunan. Setelah berhasil menjalankan perintah oleh kompeni, wedana tersebut diberi dua gelar sekaligus yaitu gelar Rangga dan Demang dan nama tersebut diabadikan menjadi nama sungai dan kampung. Setelah menyelesaikan perintah lainnya, yaitu menerima seorang tamu gubernur jenderal dengan memuaskan, wedana tersebut menerima penghargaan lainnya yaitu Aria. Semenjak saat itu,wedana dikenal sebagai Aria Banjaran.

Dalam cerita lain yaitu "Sunan Permana Dippuntang", berlatar kisah kerajaan. Cerita ini menggambarkan Kerajaan Pajajaran secara umum dan tentang asal-usul nenek moyang dari keturunan Pajajaran yang juga menerangkan beberapa peristiwa yang menerangkan tempat-tempat seperti gunung, kuburan, dan nama tempat lainnya (1978).

Kisah lainnya yang juga meninggalkan jejak sejarah tertuang dalam sastra lisan yang berjudul "Kakek Parana Nenek Parana". Garis besar dari cerita ini adalah sejarah Majapahit. Alkisah hiduplah sepasang suami istri yang bernama Kakek Parana dan Nenek Parana, mereka tinggal di Blok Majapahit. Mereka berdua adalah orang "sakti" karena mempunyai ilmu yang menjadi pegangannya sehingga setiap hasil pertanian dan tanamannya tumbuh subur dan memiliki hasil yang melimpah, Mantra yang sering diucapkan oleh mereka adalah mantera kegagahan, biasa diucapkan pada malam hari oleh Kakek Prana, sedangkanmantra yang dikuasai Nenek Prana adalah mantra pekasih. Mantra-mantra diucapkan sebelum tidur.

Masih dalam cerita yang sama, di pagi hari ketika Kakek dan Nenek Parana bangun, mereka tampak sedih mendapati lahan perkebunan dan pertanian mereka rusak oleh seekor kerbau dan keberadaan kerbau itu pun lenyap entah kemana. Kemudian mereka bermunajat di bawah pohon Majapahit, hingga seketika itu muncullah Kuda Sembagi dan Kuda Pangrawit untuk mengajak kembali mereka ke Cirebon, tetapi kakek dan nenek itu tidak ingin pergi dari tempatnya. Diajukanlah syarat kepada merekaberdua: merekaharusmendatangkanJakaSundang, anakKakekdanNenek Parana. Datanglah Jaka Sundang. Untuk meyakinkan mereka, Jaka Sundang harus masuk dan mandi di dalam kendi. Dipenuhilah persyaratan mereka dan masuklah Jaka Sundang ke 
dalam kendi dan si Kakek menutup kendi itu dengan rapat. Jaka Sundang memohon untuk dilepaskan, tetapi si Kakek memberi syarat bahwa dia harus mengantarnya ke selatan Cirebon. Sesampainya di sana, kemudian kakek-nenek itu pun menghilang, sebagai tanda tumbuhlah dua batang hanjuang merah dan putih sebagai sebuah pesan untuk mencari jejak sejarah Majapahit (1978). Masih ada beberapa cerita serupa yang menceritakan sejarah zaman dahulu kala yang terlukis melalui sastra lisan Sunda dan cerita yang diangkat cenderung sama bertujuan memberitahukan kepada generasi saat ini tentang asal usul atau sejarah masa lalu mereka.

\section{Sastra Lisan Banjar}

Beragam jenis kesusastraan Banjar telah lama ada, hampir sama tuanya dengan kehidupan masyarakat Banjar itu sendiri. Seperti halnya karakteristik sastra lisan, sastra Banjar umumnya hidup dan tersebar dari mulut ke mulut sejak zaman nenek moyang masyarakatnya. Walaupun sudah ada usaha-usaha preservasi dan pendokumentasian, hal tersebut agak sulit untuk dilakukan, karena ada kecenderungan untuk mengubah, menambah atau mengurangi sastra lisan yang ada untuk menyesuaikan dengan selera penggarapnya, sehingga kadangkadang keaslian dari kekhasan sastra Banjar itu sendirihilang (Sunarti, 1978). Oleh karena itu, dalam buku Sastra Lisan Banjar, Sunarti dkk. merangkum sastra lisan Banjar yang didapat melalui penelitian, di antaranya adalah kisah mengenai asal-usul tempat, asal-usul benda, legenda, cerita humor, kisah hantu dan raksasa, pantun, puisi, syair, prosa liris, andi-andi, prosa liris, lamut, mitos, kisah-kisah Datu, sage, prosa, fabel, mamanda, mahidin dan wayang Banjar. Berikut adalah kisah yang dikenal dengan Asal Usul Keris Naga Salira.

Diceritakan bahwa terdapat sebuah kerajaan bernama Negara Dipa yang belum mempunyai raja, dan sementara diperintah oleh Putri Junjung Buih. Putri dianggap tidak tepat memimpin oleh Mahapatih Lambung Mangkurat yang sangat berpengaruh di Negara Dipa. Oleh karena itu, berdasarkan firasat yang didapat saat semedi, dia berangkat ke Majapahit untuk mencari seorang raja bagi Negara Dipa yang nantinya juga akan mempersunting Putri Junjung Buih.

$$
\text { Sesampainya di Majapahit, }
$$

Lambung Mangkurat menemui Raja dan menyampaikan maksud kedatangannya. Raja pun memahami hal itu, lalu menyuruh Lambung Mangkurat untuk memilih salah satu dari putera Majapahit untuk dibawa ke kerajaan Negara Dipa. Setelah memilih, Lambung Mangkurat menunjuk seorang putra yang rupanya sangat jelek dan tubuhnya bulat seperti semangka, kalau berjalan maka dia hanya akan menggelinding saja. Raja membiarkan pilihan tersebut dan mengizinkan mereka kembali ke Negara Dipa.

Dalam perjalanannya kembali dengan kapal, saat sudah memasuki muara, anehnya kapal tersebut tidak bisa berlabuh di pelabuhan. Lambung Mangkurat yang mempunyai firasat lalu bersemedi. Di dalam semedinya, Lambung Mangkurat melihat seekor naga putih sedang melilit bagian bawah kapal. Naga putih tersebut meminta agar disediakan 40 macam sesajen, serta sebuah gong besar sebagai tempat berpijaknya putra raja Majapahit yang nantinya akan naik ke kepala naga tersebut, karena naga itulah yang akan membawa putra raja ke darat. Permintaan itu disanggupi dan disediakan segera setelah Maha Patih selesai semedi. Setelah itu, muncullah naga putih dari permukaan air dan putra Raja yang sudah mengetahui cerita tentang naga tersebut pun segera menggelinding mendekat lalu duduk di atas gong yang diletakkan di atas kepala naga.

Keajaiban terjadi, saat putra Raja langsung berubah menjadi pemuda tampan dan gagah perkasa. Selanjutnya perlahanlahan naga bergerak ke daratan, dan sesampainya di sana tiba-tiba naga putih 
menjulurkan lidahnya yang kemudian dicabut oleh putra Raja. Lidah tersebut berubah menjadi sebilah keris yang kemudian dinamai sebagai keris Naga Salira yang berarti lidah naga. Keris tersebut lalu menjadi senjata putra Raja Majapahit, yang sejak saat itu memerintah kerajaan Negara Dipa setelah menikahi Putri Junjung Buih. Raja baru tersebut memakai nama Pangeran Surianata, dan demikianlah keris Naga Salira pun menjadi benda pusaka masyarakat Banjar.

\section{Sastra Lisan Kerinci}

Selain Minangkabau, di Sumatera terdapatpula sebuah daerah dengan kekayaan tradisinya yaitu Kabupaten Kerinci. Sastra lisan Kerinci didukung oleh bahasa daerahnya yaitu bahasa Kerinci. Bahasa Kerinci dipakai dalam wilayah Kabupaten Kerinci di Provinsi Jambi. Bahasa Kerinci adalah salah satu di antara keluarga bahasa Austronesia, yang termasuk ke dalam kelompok bahasa Sumatera. Secara geografis wilayah Kerinci terletak pada pertemuan tiga provinsi yaitu Sumatera Barat di sebelah utara dan barat, Jambi sebelah utara dan timur, dan Bengkulu di sebelah selatan. Ketiga provinsi yang mengapit daerah Kerinci ini memiliki bahasa yang berbedabeda pula(Syamsudin, 1985)

Salah satukeunikan dari sastra Kerinci adalah tidak pernah dikenal adanya sastra tulis. Bentuksastra yang hidup dan berkembang adalah sastra lisan.Oleh karena itu, sastra lisan Kerinci yang merupakan warisanbudaya bangsa perlu untuk diselamatkan keberadaannya.

Sastra rakyat Kerinci menurut bentuknya dapat diklasifikasikan sebagai prosa, puisi, dan prosa liris. Jenis sastra Kerinci yang termasuk ke dalam kelompok prosa, seperti yang dikutip dalam Karimi (1969) adalah kunaung, dongeng, cerita penggeli hati, cerita pelipur lara, cerita perumpamaan, cerita pelengah, dan kunan baru (Syamsudin, 1985).

Untuk mengungkapkan jejak-jejak sejarah yang terdapat pada sastra lisan
Kerinci, selanjutnya difokuskan pada bentuk sastra kunun (kunaung).

Kunaung adalah bentuk cerita yang dilagukan. Tidak semua orang memilki kemampuan untuk melagukan kunaung. Orang-orang yang dapat melagukan kunaung disebut tukang kunaung (hlm. 10). Berkunaung biasa dilakukan pada malam hari. Biasanya selama mendengar pelantunnya berkunaung, pendengarnya tidak mengantuk. Meskipun mata terpejam, telinga mereka tetap mengikuti jalan cerita. Berkunaung dilakukan dengan khalayak yang melingkar, duduk bersila, sambil tiduran, ataupun sambil bersandar di dinding (hlm. 11). Kunaung termasuk salah satu sastra lisan; ada yang dapat diceritakan saja, dilagukan, dan juga ada yang dilagukan dengan diiringi alat musik tradisional tertentu. Dalam penelitian yang dilakukan Pusat Pembinaan dan Pengembangan Bahasa Departemen Pendidikan dan Kebudayaan Jakarta tahun 1985 telah terkumpul sebanyak 21 cerita (kunaung). Sebelas diantaranya disampaikan tanpa menggunakan alat musik. Dari ke-21 judul cerita tersebut hanya cerita Rajo Alam, silsilah Raja kita yang mengandung jejak-jejak sejarah. Adapun cerita lainnya hanya mengisahkan nilai-nilai moral, nilai-nilai kehidupan, pendidikan dan hiburan. Berikut adalah ringkasan cerita yang di dalamnya terkandung jejak-jejak sejarah. Cerita "silsilah raja kita" adalah cerita yang menggambarkan keberadaan raja-raja sejak dahulu kala

Kisah yang diangkat di dalam sastra lisan tersebut memuat urutan peristiwa Nabi Adam dalam menjalani hidupnya. Ia diceritakan berada di tanah Mekah, selanjutnya di Madinah, Tarin, dan Baitulmaqdis.

Urutan peristiwa ini merupakan rangkain penggalan sejarah yang bertautan dengan peristiwa Nabi Adam yang melakukan perjalanan di luar teks. Cerita yang dikisahkan dengan merujuk pada peristiwa sejarah Islam memberikan gambaran kepada pendengarnya bahwa 
terdapat sebuah peristiwa yang tidak dapat begitu saja dilepaskan dengan konteksnya.

Implikasi sederhana dari hadirnya pengggalan kisah Nabi Adam dalam sastra lisan tersebut adalah kedekatan masyarakat dengan cerita yang mengandung muatan Islam yang hadir di tengah masyarakat Kerinci. Meskipun sulit untuk menangkap kisah tersebut sebagai fakta sejarah secara utuh mengingat adanya unsur glorifikasi berlebih terhadap peristiwa yang terjadi. Tentunya ini menimbulkan subjektivitas yang tinggi pada pesan yang hendak disampaikan.

\section{Sastra Lisan Sentani}

Sentani adalah sebuah daerah yang terletak di kaki Gunung Siklop di Kabupaten Jayapura, yang merupakan salah satu sumber kekayaan sastra lisan nasional kita. Sentanimenjadi salah satu sumber sastra lisan yang dapat dipelajari untuk menguak berbagai informasi (Fatubun, 2000). Pada umumnya orang Sentani mengenal dua bahasa yaitu bahasa Indonesia dan Bahasa Sentani atau Phuyakha Afaeu. Bahasa Sentani tergolong dalam bahasa nonAustronesia dengan 3 dialek yaitu dialek Sentani Barat, Sentani Tengah, dan Sentani Timur (hlm.9)

Sastra lisan di Sentani yang telah diteliti berjumlah 26 buah, penutur sastra lisannya terdiri atas laki-laki perempuan, baik tua maupun muda. Tidak ada syarat khusus untuk menuturkan cerita-cerita ini. Para penutur pertama kali mendengar cerita-cerita itu dari kakek, nenek, orang tua lain atau siapa saja yang bisa bercerita. Semua penutur adalah orang Sentani asli yang dapat berbahasa Sentani (Fatubun, 2000). Menurut Fatubun (Fatubun, 2000), tujuan bercerita masyarakat Sentani adalah memberikan informasi tentang lingkungan masyarakat setempat, adat istiadat setempat melalui perbuatan, tingkah laku, tutur kata, dan lain sebagainya; memetik ajaran-ajaran moral dan mengisi waktu senggang (hlm.26). Tidak ada cara khusus untuk menceritakan sastra lisan Sentani, tetapi biasanya pada saat bercerita seseorang perlu sambil merokok atau mengunyah pinang. Untuk mengidentifikasi jejak sejarah yang terdapat pada sastra lisan Sentani, sampel yang digunakan adalah cerita Terjadinya Danau Sentani. Terdapat lima versi dari cerita ini yang disampaikan oleh lima orang yang berbeda. Versi yang digunakan untuk keperluan tulisan ini adalah kisah yang telah didokumentasikan secara cetak.

Sastra lisan ini berupaya untuk menyampaikan asal muasal terjadinya Danau Sentani. Kisah yang diangkat lebih condong pada penguatan pesan moral dibalut dengan peristiwa lahirnya Danau Sentani. Tidak adanya gambaran spesifik mengenai proses danau terbentuk memberikan kesan bahwa fakta sejarah yang hendak disampaikan terbatas pada bentuk nyata, yaitu Danau Sentani.

Setidaknya ada beberapa hal riil yang hendak digambarkan, yaitu, gunung siklop, Danau Sentani dan batu yang dipercaya sebagai penjernih air. Sementara itu, cerita lainnya cenderung memperkuat imajinasi tentang lahirnya sebuah peristiwa melalui kekuasan sang pencipta tanpa adanya proses ilmiah yang dapat ditelusuri keberadaannya secara nyata.

Pada akhirnya, fakta sejarah yang disampaikan tentang asalmuasal Danau Sentani terbatas pada kekuatan imajinasi yang tak dapat diuraikan menjadi penggalan-penggalan sejarah.Namun, beranjak dari hal tersebut ada hal yang dapat dijadikan rujukan bahwa Danau Sentani memiliki sejarah yang jika ditelusuri dapat berdampingan dengan sastra lisan yang telah ada.

\section{PENUTUP}

Jenis sastra lisan yang mengandung jejakjejak sejarah dapat ditemukan pada hampir setiap sastra lisan yang menjadi objek kajian, meskipun disadari bahwa jumlahnya sangat sedikit. Kebanyakan jejak-jejak sejarah dalam sastra lisan tersebut menceritakan asal-muasal kemunculan nama suatu tempat, dan kehidupan masa lalu raja-raja. Isi dari sastra lisan tersebut terkadang cenderung 
melebih-lebihkan, tetapi memang perlu disadari bahwa dalam proses penyampaian maupun isi dari sastra lisan tersebut tidaklah boleh terlalu berat isinya, karena menyesuaikan dengan kondisi pada masyarakat pada waktu itu.

Akhirnya, untuk merekam jejakjejak sejarah pada berbagai sastra lisan lainnya dibutuhkan penelitian yang lebih komprehensif dan menyeluruh, sehingga mampu untuk menelusuri lebih jauh jejakjejak searah apa saja dan jenis sejarah macam apa yang terdapat pada masingmasing sastra lisan tersebut dan kaitannya dengan sejarah yang benar-benar terjadi di kehidupan nyata. Keterbatasan terhadap metode, teori dan data penelitian tentu saja menjadi salah satu kendala untuk mengupas lebih tuntas mengenai fakta sejarah yang ada.

\section{DAFTAR PUSTAKA}

Amir, A. (2013). Sastra Lisan Indonesia. Yogyakarta: Andi Publisher.

Aritonang, B., Kurniawati, W., Mukhamdanah, Palupi, D., Yulianti, S., \& Inayatusshalihah. (2017). Bahasa dan Peta Bahasa di Indonesia (4th ed.). Jakarta: Badan Pengembangan dan Pembinaan Bahasa.

Bakar, D. (1979). Kaba Minangkabau 1. Jakarta: PPPB Departemen Pendidikan dan Kebudayaan.

Danandjaja, J. (1991). Foklor Indonesia Ilmu Gosip, Dongeng, dll. Jakarta: PT. Pustaka Utama Grafiti.

Darman, F. (2017). Realitas Sejarah dalam Sastra Lisan Kapata Perang Kapahaha Desa Morella, Pulau Ambon. Kapata Arkeologi, 13(2), 131-140.

Dirija, I. N. (2005). Tradisi Lisan, Naskah, dan Sejarah Sebuah Catatan Politik Kebudayaan. Wacana, 7(2), 111-124.

Djamaris, E. (1991). Tambo Minangkabau Suntingan Teks Si Sertai Analisis Struktur. Jakarta: Balai Pustaka.

Erman, E. (2011). Penggunaan Sejarah Lisan dalam Historiografi Indonesia. Jurnal Masyarakat \& Budaya, 13(1),
$1-22$.

Fachruddin. (1981). Sastra Lisan Bugis. Jakarta: PPPB Departemen Pendidikan dan Kebudayaan.

Fakta Sejarah dalam Karya Sastra Indonesia | Direktorat Jendral Kebudayaan. (2016). Retrieved April 1, 2020, from https://kebudayaan.kemdikbud.go.id/f akta-sejarah-dalam-karya-sastraindonesia $/+\& \mathrm{~cd}=7 \& \mathrm{hl}=\mathrm{en} \& \mathrm{ct}=\mathrm{clnk} \&$ $\mathrm{gl}=\mathrm{id}$

Fatubun, R. (2000). Struktur Sastra Lisan Sentani. Jakarta: PPPB Departemen Pendidikan dan Kebudayaan.

Hutomo, S. S. (1991). Mutiara yang Terlupakan Pengantar Studi Sastra Lisan. Jawa Timur: Himpunan Sarjana Kesusastraan Indonesia Hiski.

Khakim, M. N. L. (2016). Telaah Penulisan Karya Sastra Sejarah sebagai Refleksi Sumber Pembelajaran Sejarah. Sejarah Dan Budaya, 10(1), 94-99.

Koentjaraningrat. (2009). Pengantar Ilmu Antropologi. Jakarta: Rineka Cipta.

Laili, N. (2013). Kajian Historisisme dalam Novel Keindahan dan Kesedihan Karya Yasunari Kawabata. Diglossia: Jurnal Kajian Ilmiah Kebahasaan Dan Kesusastraan, 4(2), $1-11$.

Lord, A. B. (1971). The Singer of Tales. New York: Atheneum.

Ratna, N. K. (2010). Sastra dan Cultrual Studies Representasi Fiksi dan Fakta. Yogyakarta: Pustaka Pelajar.

Rusyana. (1978). Sastra Lisan Sunda. Jakarta: PPPB Departemen Pendidikan dan Kebudayaan.

Sunarti. (1978). Sastra Lisan Banjar. Jakarta: PPPB Departemen Pendidikan dan Kebudayaan.

Syamsudin, U. (1985). Struktur Sastra Lisan Kerinci. Jakarta: PPPB Departemen Pendidikan dan Kebudayaan.

Taum, Y. Y. (2011). Studi Sastra Lisan. Yogyakarta: Lamalera. 